\title{
Perfect date-the review of current research into molecular bases of mammalian fertilization
}

\author{
Zuzana Trebichalská ${ }^{1} \cdot Z_{\text {Zuana Holubcová }}{ }^{1,2}$ \\ Received: 11 November 2019 / Accepted: 22 December 2019 / Published online: 6 January 2020 \\ (C) The Author(s) 2020
}

\begin{abstract}
Fertilization is a multistep process during which two terminally differentiated haploid cells, an egg and a sperm, combine to produce a totipotent diploid zygote. In the early 1950s, it became possible to fertilize mammalian eggs in vitro and study the sequence of cellular and molecular events leading to embryo development. Despite all the achievements of assisted reproduction in the last four decades, remarkably little is known about the molecular aspects of human conception. Current fertility research in animal models is casting more light on the complexity of the process all our lives start with. This review article provides an update on the investigation of mammalian fertilization and highlights the practical implications of scientific discoveries in the context of human reproduction and reproductive medicine.
\end{abstract}

Keywords Fertilization · In vitro fertilization · Gamete biology $\cdot$ Human reproduction

\section{Introduction}

Reproduction ensures the maintenance of a population and the evolution of all species. The ability to produce viable gametes, along with mating strategies resulting in encounters and the union of these highly differentiated cells, is essential for all mammals. Although the fertilization process is central for the reproduction of our species, its molecular bases remain poorly understood. Since experimentation on humans is hindered by ethical, technical, and regulatory challenges, the animal models are employed to explore fundamental principles of sperm-egg interaction. Here, we recapitulate current knowledge of the mammalian fertilization, especially focusing on newly identified molecular players involved in (1) oocyteinduced sperm hyperactivation, (2) mutual gamete recognition and binding, (3) oocyte activation, and (4) prevention of polyspermy. The published research findings are critically discussed in relation to their role in human fertility treatment, reproductive toxicity, and birth control. The last section is

Zuzana Holubcová

zholub@med.muni.cz

1 Faculty of Medicine, Department of Histology and Embryology, Masaryk University, Kamenice 5, Brno, Czech Republic

2 Reprofit International, Clinic of Reproductive Medicine, Brno, Czech Republic dedicated to future directions in the field of fertility research and reproductive medicine.

\section{Oocyte-induced sperm hyperactivation}

Only high-quality gametes that meet stringent selection criteria can conceive a new life. Very few of the millions of ejaculated spermatozoa are selected by the female reproductive tract to gain access to the fertilization site. On their epic journey, male gametes have to use their limited resources and overcome multiple mechanical and chemical impediments [1]. The interaction with fluids secreted by the female reproductive system facilitates sperm functional maturation. This process called "capacitation" involves complex modification in the molecular landscape of the sperm plasma membrane. Exposure of the membrane receptors is essential for the spermatozoon to acquire the full capacity to interact with the ovulated egg. Molecular details of the capacitation process have been comprehensively reviewed elsewhere and are not covered here [2, 3]. Simultaneously, multiple external cues alter sperm motility and swimming patterns. Biochemical signals present in the female reproductive tract cause a shift of flagellar movement from a low amplitude and regular symmetric beat, into a short asymmetric pounding. Such a vigorous type of motility is believed to generate a more powerful force which enhances release of sperm from the oviductal reservoirs, their efficient movement in viscoelastic luminal 
fluids, invasion of the cumulus oophorus, and ultimately penetration of the glycoprotein-rich mesh of zona pellucida (ZP) $[4,5]$. The transformation of the sperm motility pattern is called "hyperactivation" and, along with capacitation, renders the sperm competent to fertilize the ovum.

There is a plethora of regulatory pathways that control the physiology of human spermatozoa. Among them, the elevation of intracellular calcium $\left(\mathrm{Ca}^{2+}\right)$ is a key signaling element implicated in sperm maturation, motility, chemotaxis, and acrosome reaction, all of which are critical for the success of fertilization. Free intracellular $\mathrm{Ca}^{2+}$ ions exert instant allosteric regulatory effects on enzymes and proteins and act as a second messenger ensuring the transduction of the information from membrane receptors to downstream effector molecules. Animal studies using a demembranated sperm model showed that $\mathrm{Ca}^{2+}$ acts directly on cytoskeletal components of the flagellum to regulate sperm motility $[6,7]$. The change from basal to hyperactivated motility is triggered by a rapid rise of intracellular concentration of $\mathrm{Ca}^{2+}\left(\left[\mathrm{Ca}^{2+}\right]\right.$ i) resulting from an influx of $\mathrm{Ca}^{2+}$ across the sperm plasma membrane. The experimental data obtained from the application of "patch-clamp" recordings have revealed the central role of the CatSper channel in $\mathrm{Ca}^{2+}$ signaling.

\section{CatSper: unique $\mathrm{Ca} 2+$ channel of sperm flagellum}

The CatSper is a weakly voltage-gated and $\mathrm{pH}$-sensitive ion channel with a high affinity to divalent cations $[8,9]$. This multi-protein complex is composed of four pore-forming subunits CatSper1-4 and five accessory subunits encoded by at least nine genes in mammals $[10,11]$. The structure and distribution of its subunits are integral for the channel function [11-13]. The expression of CatSper proteins is testis-specific with localization confined to the surface of the sperm tail [14]. Genetic evidence shows that the function of CatSper channel proteins is indispensable for male fertility. The knockout mice were sterile despite having normal sperm count and morphology. Their spermatozoa exhibited impaired motility and failed to penetrate ZP [12]. In humans, genetic lesions and altered expression profiles of CatSper genes have been clinically linked to asthenoteratospermia and male infertility [15-19].

To achieve fertilization, hyperactivated motility must be switched on at the right place and time. The ability of $\mathrm{Ca}^{2+}$ to evoke asymmetric flagellar beating is known to be primed by increased $\mathrm{pH}$ [20]. But how the capacitation-induced rise of intracellular $\mathrm{pH}$ regulates $\mathrm{Ca}^{2+}$ influx was unclear. Recently, SLC9C1, a sperm-specific $\mathrm{Na} / \mathrm{H}^{+}$exchanger mediating chemoattractant-induced intracellular alkalization, has been identified as a gatekeeper at the pore of the CatSper channel [21]. The elevation of intracellular $\mathrm{Ca}^{2+}$ in the sperm tail induces a conformational change of the blocker molecule. Subsequent dissociation of the SLC9C1 opens the CatSper channel for the $\mathrm{Ca}^{2+}$ entry [22] (Fig. 1). This finding provides molecular explanation for CatSper sensitivity to $\mathrm{pH}$. In vivo, oviduct lumen $\mathrm{pH}$ increases after ovulation thus providing favorable conditions for sperm hyperactivation [23]. Yet, some researchers intuitively searched for a more specific physiological stimuli produced by the female reproductive tract.

Two simultaneously published studies revealed an unprecedented role of sex hormone progesterone as a hyperactivationinducing factor $[24,25]$. This female steroid hormone, secreted by cumulus cells that surround the oocyte after ovulation, is a well-known chemoattractant for mammalian spermatozoa [26]. The nanomolar concentration of progesterone has been shown to dramatically potentiate hyperactivated flagellar movement of human spermatozoa in an alkaline environment. Surprisingly, progesterone-induced hyperactivation does not involve a slow canonical pathway of interaction with nuclear receptor and alteration of gene expression. Instead, the steroid hormone binds to a membrane receptor on the extracellular side of the cell bringing about a CatSper-mediated influx of $\mathrm{Ca}^{2+}$. The nongenomic action of progesterone on CatSper is intermediated by $\alpha / \beta$ hydrolase domain-containing protein 2 (ABHD2) which serves as a progesterone receptor on the sperm membrane. Upon progesterone binding, lipid hydrolase ABHD2 degrades endocannabinoid 2-arachidonoylglycerol (2AG) present on the sperm membrane. The replenishment of AG2 leads to the CatSper opening and triggers sperm hyperactivation (Fig. 1). Since ejaculated human spermatozoa retain a substantial amount of $2 \mathrm{AG}$, progesterone-stimulated removal of $2 \mathrm{AG}$ by ABHD2 is required for full activation of CatSper [27]. Similar to progesterone, prostaglandin E1 (PGE1) stimulates the activity of human CatSper, but apparently through a different binding site [24]. Structural similarity of PGE1 with a 2AG tail implies that there might be direct competition between PGE1 and $2 \mathrm{AG}$ [27]. Further research is needed to test this hypothesis and provide a robust insight into how PGE1 regulates the function of the CatSper channel. Although both mouse and human CatSper are pH-sensitive, mouse CatSper is not activated by progesterone or prostaglandins [24]. The interspecies differences in expression and function of this ion channel can be attributed to the low degree of sequence identity between orthologs of CatSper units [28]. For this reason, mice "knockout" models cannot be used to investigate and progesterone/ PGE1-mediated hyperactivation pathway.

The ligand-sensitive nature of human CatSper activation predisposes human sperms to be modulated by various compounds which bind to the extracellularly accessible site of this channel complex. Physiological stimuli which have been recognized to induce CatSper-dependent $\mathrm{Ca}^{2+}$ entry include glycoproteins of ZP, serum albumin, and cyclic nucleotides [29, 30]. The predominant expression in sperm makes the CatSper channel an attractive target for modulation of male fertility [31-33]. For instance, steroid-like plant terpenoids, lupeol and pristimentin, were identified as potent inhibitors of hyperactivation of capacitated spermatozoa. Both molecules compete with progesterone for its binding site on $\mathrm{ABHD} 2$ and can 

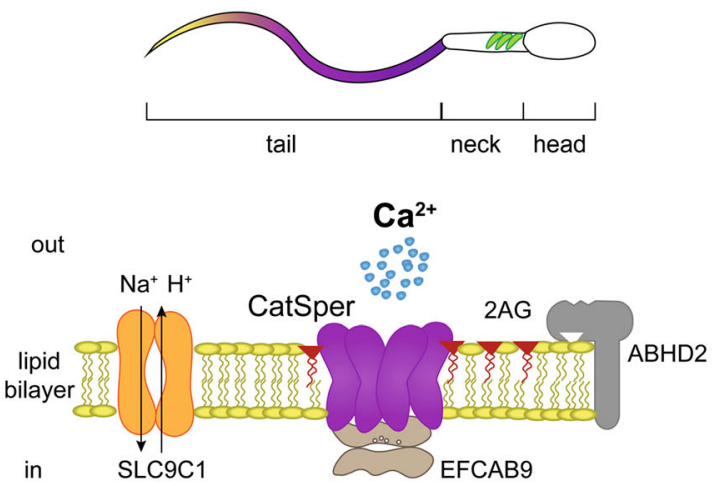

Fig. 1 The role of $\mathrm{Ca}^{2+}$ signaling in sperm hyperactivation. Progesteroneinduced activation of the CatSper channel in an alkaline environment allows rapid $\mathrm{Ca}^{2+}$ influx which, along with mobilization of $\mathrm{Ca}^{2+}$ from

thus act as contraceptive compounds. Interestingly, both testosterone and hydrocortisone were found to antagonize the action of progesterone at physiological concentrations, which may explain why elevated levels of these steroids in the female organism adversely affect fertility [34]. Importantly, a range of structurally diverse molecules including environmental pollutants, endocrine disruptors, odorants, and common drugs have been shown to interact with the CatSper and interfere with hyperactivation signaling (Table 1) [30, 35-41]. These exogenous chemicals desensitize spermatozoa to physiological CatSper agonists and thus may impair their functional competence. Future studies that would determine safety thresholds for acute and chronic exposure to these substances for men s reproductive health are urgently needed. Taken together, the CatSper channel serves as a polymodal sensor that integrates various chemical clues from the surrounding microenvironment and translates them into $\mathrm{Ca}^{2+}$ signaling patterns, which, in turn, modulates the amplitude of flagellar beating. The complex regulation of motility might be functionally important for navigation of sperm over long distances to reach the site of fertilization.

The vital role of CatSper-mediated influx of $\mathrm{Ca}^{2+}$ from the extracellular fluid is generally recognized. But there is also a piece of good evidence for the functional significance of $\mathrm{Ca}^{2+}$ stored in intracellular organelles. Unlike most cells, mature spermatozoa do not contain endoplasmic reticulum, which is a primary $\mathrm{Ca}^{2+}$ storage organelle. Potential areas for functional $\mathrm{Ca}^{2+}$ store in sperm include acrosome, mitochondria in the midpiece and redundant nuclear envelope in the connecting piece $[42,43]$. The exact mechanism of $\mathrm{Ca}^{2+}$ mobilization from internal reservoirs remains to be elucidated. In the tentative model,
HYPERACTIVATION
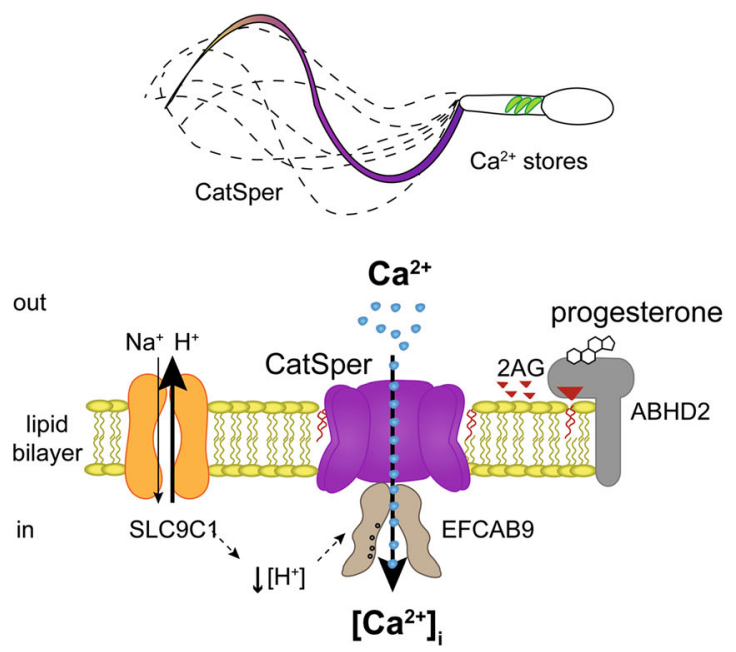

the storage organelles, elevates intracellular $\mathrm{Ca}^{2+}$, thus generating the hyperactivated sperm motility

CatSper-mediated elevation of flagellar $\left[\mathrm{Ca}^{2+}\right] \mathrm{i}$ spreads forward and stimulates the secondary release of stored $\mathrm{Ca}^{2+}$ thus leading to hyperactivation $[43,44]$. Apart from the conventional store-mobilizing agonists, vitamin D or peptide hormones kisspeptin and ghrelin might be involved in the mobilization of $\mathrm{Ca}^{2+}$ in hyperactivated human sperm [43]. Although the evidence is preliminary, it is tempting to speculate that pharmacological activation of stored $\mathrm{Ca}^{2+}$ release might help to bypass the adverse effects on motility caused by impaired function of the CatSper.

\section{Sperm-egg association}

The union of an egg with a sperm is a central event of the fertilization process. It involves the stages of the initial approach, molecular recognition, membrane apposition, and the merger of the plasma membrane lipids [45, 46]. To get into physical contact with the oolemma, the spermatozoa have to actively invade the cumulus and bore through the matrix of the ZP (details of this fertilization step are reviewed elsewhere [47, 48]). Acrosome reaction results in exposure of a new set of surface antigens thus priming the sperm for fusion with the oolemma. After reaching perivitelline space, the spermatozoa adhere to membrane protrusions, known as microvilli which densely cover the surface of the oocyte. These actin-filled hairlike projections greatly enlarge the contact area and decrease the repulsion between the two juxtapositioned membranes [49]. In many animal species, sperms have a preferential entry point [50-52]. In mouse, rat, and hamster eggs, sperm do not fuse with the microvilli-free 
Table 1 Overview of the identified low molecular interactors of the CatSper channel

\begin{tabular}{|c|c|c|c|c|c|c|}
\hline Type & Category & Name & $\begin{array}{l}\text { CAS } \\
\text { number }\end{array}$ & Concentration & Effect & Reference \\
\hline \multirow[t]{6}{*}{ endogenous } & \multirow[t]{5}{*}{ steroids } & progesterone & $57-83-0$ & $\mathrm{nM}$ & agonist & Lishko et al., 2011 [24] \\
\hline & & & & & & $\begin{array}{l}\text { Strunker et al., } 2011 \\
\text { [25] }\end{array}$ \\
\hline & & testosterone & $58-22-0$ & $\mathrm{nM}$ & $\begin{array}{l}\text { partial } \\
\text { agonist }\end{array}$ & $\begin{array}{l}\text { Mannowetz et al., } 2017 \\
\text { [34] }\end{array}$ \\
\hline & & estrogen & $50-28-2$ & $\mathrm{nM}$ & $\begin{array}{l}\text { partial } \\
\text { agonist }\end{array}$ & $\begin{array}{l}\text { Mannowetz et al., } 2017 \\
\text { [34] }\end{array}$ \\
\hline & & hydrocortisone & $50-23-7$ & $\mathrm{nM}$ & $\begin{array}{l}\text { partial } \\
\text { agonist }\end{array}$ & $\begin{array}{l}\text { Mannowetz et al., } 2017 \\
\text { [34] }\end{array}$ \\
\hline & endocannabidoids & 2-arachidonoylglycerol & $53847-30-6$ & $\mu \mathrm{M}$ & antagonist & Miller et al., 2016 [27] \\
\hline \multirow[t]{17}{*}{ exogenous } & $\begin{array}{l}\text { analogues of cyclic } \\
\text { nucleotide }\end{array}$ & $\begin{array}{l}\text { 8-bromoguanosine 3',5'-cyclic } \\
\text { monophosphate }\end{array}$ & $31356-94-2$ & $\mathrm{mM}$ & agonist & Brenker et al., 2012 [30] \\
\hline & \multirow[t]{2}{*}{ triterpenoids } & pristimerin & $1258-84-0$ & $\mathrm{nM}$ & $\begin{array}{l}\text { partial } \\
\text { agonist }\end{array}$ & $\begin{array}{l}\text { Mannowetz et al., } 2017 \\
{[34]}\end{array}$ \\
\hline & & lupeol & $545-47-1$ & $\mathrm{nM}$ & $\begin{array}{l}\text { partial } \\
\text { agonist }\end{array}$ & $\begin{array}{l}\text { Mannowetz et al., } 2017 \\
\text { [34] }\end{array}$ \\
\hline & \multirow[t]{2}{*}{ nonsteroidal estrogens } & \multirow[t]{2}{*}{$\alpha$-zearalenol } & \multirow[t]{2}{*}{$36455-72-8$} & \multirow[t]{2}{*}{$\mu \mathrm{M}$} & \multirow[t]{2}{*}{ agonist } & Brenker et al., 2018 [41] \\
\hline & & & & & & $\begin{array}{l}\text { Schiffer et al., } 2014 \\
\text { [36] }\end{array}$ \\
\hline & \multirow[t]{2}{*}{ endocrine disruptor } & dichlorodiphenyldichloroethylene & $72-55-9$ & $\mathrm{pM}-\mu \mathrm{M}$ & agonist & Tavares et al., 2013 [35] \\
\hline & & diethylstilbestrol & $56-53-1$ & $\mathrm{pM}-\mu \mathrm{M}$ & agonist & Zou et al., 2017 [40] \\
\hline & plasticizers & dibutyl phtalate & $84-74-2$ & $\mu \mathrm{M}$ & agonist & Schiffer et al., 2014 [36] \\
\hline & anesthetic & ketamine & $6740-88-1$ & $\mathrm{mM}$ & antagonist & He et al., 2016 [38] \\
\hline & \multirow[t]{4}{*}{ odorants } & bourgeonal & $18127-01-0$ & $\mu \mathrm{M}$ & agonist & Brenker et al., 2012 [30] \\
\hline & & undecanal & $112-44-7$ & $\mu \mathrm{M}$ & agonist & Brenker et al., 2012 [30] \\
\hline & & cyclamal & $103-95-7$ & $\mu \mathrm{M}$ & agonist & Brenker et al., 2012 [30] \\
\hline & & helional & $1205-17-0$ & $\mu \mathrm{M}$ & agonist & Brenker et al., 2012 [30] \\
\hline & \multirow[t]{4}{*}{ UV filters } & benzylidene camphor sulfonic acid & $56039-58-8$ & $\mu \mathrm{M}$ & agonist & Brenker et al., 2018 [41] \\
\hline & & 4-methylbenzylidene camphor & $36861-47-9$ & $\mu \mathrm{M}$ & agonist & Rehfeld et al., 2016 [37] \\
\hline & & methyl anthranilate & $134-20-3$ & $\mu \mathrm{M}$ & agonist & Rehfeld et al., 2016 [37] \\
\hline & & isoamyl p-methoxycinnamate & $71617-10-2$ & $\mu \mathrm{M}$ & agonist & Rehfeld et al., 2016 [37] \\
\hline
\end{tabular}

cortical area overlying the meiotic spindle [53, 54]. On the contrary, in sperm-receptive human oocytes, microvilli are uniformly distributed all over the oocyte surface [55] suggesting that, in humans, the sperm entry can occur anywhere on the oocyte surface. Nevertheless, this does not exclude the existence of plasma membrane microdomains which would facilitate sperm adherence and thus serve as fertilization "hot spots" on the surface of a human egg [56].

The molecular mechanisms underlying complex dialogue between sperm and egg have been widely investigated in the mouse model. In vitro fertilization experiments, immunoassays, and targeted gene disruption have been used to identify the principal receptors involved in gamete conjunction. However, the majority of putative match-making factors turned out to be nonessential for fertilization in vivo [47,
57]. To date, only three proteins, namely, CD9, Izumo, and Juno, were proven to be indispensable for gamete interaction.

\section{CD9}

CD9 was the first gene identified to have a sex-specific fertility effect. This ubiquitous membrane protein is localized to the oolemma of fertilization-competent eggs and required for normal microvilli morphology and distribution [58-60]. The observation that the monoclonal anti-CD9 antibody potently inhibits sperm-egg binding in vitro [59] indicated that this surface protein is involved in gamete interaction. Three studies independently reported that female, not male, $C D 9$-null mice exhibited a dramatic reduction of fecundity resulting from the specific failure of membrane fusion [60-62]. The details of molecular mechanism by which the loss of the CD9 function 
impairs fertilization remain to be elucidated. Based on the experiments assessing the relationship between CD9 presence and adhesion phenotypes, Jegou et al. proposed a model in which CD9-driven formation of adhesion sites facilitate the tight sperm-egg contact necessary for fusion to take place [63]. Interestingly, CD9-containing vesicles secreted by wild-type oocytes have been reported to restore the fusing ability of the CD9-deficient mouse eggs and translocate CD9-positive membrane fragments onto the sperm head before its attachment to the egg membrane $[64,65]$. These findings support the role of CD9 as an organizer of membrane architecture and suggest that not only the oolemma but also sperm membrane rearrangement is required for gamete fusion.

\section{Izumo}

Izumo, named after the Japanese shrine dedicated to marriage, is the key fertilization element expressed on the sperm surface. The antigen was identified through the generation of a monoclonal antibody that effectively blocks fertilization. The importance of this molecule has been demonstrated by knockout experiments. Izumo-/- male mice are completely sterile despite normal mating behavior and sperm production. Mutant spermatozoa can penetrate the ZP but fail to fuse with the oocytes. However, when the fusion step was bypassed by intracytoplasmic sperm injection (ICSI), activation took place and the embryos developed to term [66]. Izumo is expressed on the inner acrosomal membrane and is thus undetectable on the surface of freshly ejaculated spermatozoa. At the time of acrosome reaction, Izumo becomes exposed and diffuses from the acrosomal cap to the equatorial segment of the sperm head where gamete fusion is initiated [66, 67]. Testis-specific serine kinase TSSK6 has been implicated in this translocation process. The inability to properly redistribute Izumo can explain the absence of fusion underlying sterility of Tssk6-null male mice [68, 69]. Izumo was found to be expressed also in human sperm $[66,70]$ but, to date, there is a paucity of clinical data supporting its involvement in etiology of idiopathic infertility [71, 72]. Although active immunization against Izumo causes contraceptive effect in female mice, the plausibility of targeting Izumo, or another sperm-specific protein, for development of vaccines for human contraception remains controversial and awaits further investigation [73-75]. The discovery of two fusion-related antigens, a sperm-specific Izumo and oocyte-expressed CD9, stimulated further research into the molecular basis of sperm-egg recognition [58-60, 64]. Although both Izumo and CD9 are enriched in the adhesion area, in vitro cell binding assays revealed that there is no physical interaction between the two molecules [76, 77]. Therefore, the existence of alternative Izumo-binding factor(s) on the egg s surface has been hypothesized [77].

\section{Juno}

In 2014, Bianchi and colleagues used the recombinant probe containing IZUMO domain to find its receptor on the oocyte plasma membrane. This experiment led to the discovery of the complementary receptor Juno which was named after the ancient Roman goddess of marriage and childbirth. The observation that Juno ${ }^{-/-}$oocytes bind but do not incorporate the sperm head provided genetic evidence for the vital role of the Juno receptor in the fusion process [78]. In humans, the incidence of certain sequence variants of the Juno-encoding gene has been related to unexplained fertilization failure [79]. Analysis of the protein expression in unfertilized the metaphase II and in vitro matured human oocytes showed that Juno accumulates to the oolemma in the course of human oocyte maturation [80, 81]. Yet, fluorescent live imaging of good-quality oocytes is needed to characterize Juno dynamics prior to fertilization and explain the discrepancy between the localization patterns immunodetected in fixed and live human samples reported in this study. Of note, two recent studies reported that the exposure of the female mice to widespread environmental pollutants, melamine and benzo[a]pyrene, altered expression and localization of Juno and adversely effected mouse egg fertilizing capacity assessed in vitro [82, 83]. Future studies should address whether the similar risk of reproductive toxicity exists in humans.

The pairing of the sperm-specific protein Izumo and its oocyte-expressed counterpart Juno constitutes an initial step in gamete fusion. High-resolution imaging of ectopically expressed fluorescent proteins has been used to study receptor-ligand interaction in vitro. The results indicated that monomeric Izumo is recognized by Juno and then transferred to an unidentified egg receptor while generating robust intercellular adhesion $[66,77]$. Yet, heterologous fusion assays demonstrated that the binding of Izumo and Juno facilitates membrane tethering but it is not sufficient to trigger the union of the two cells [76]. This indicates the requirement of additional factor(s) conferring adhesion complex fusogenic property. There are many open questions concerning the interplay of key molecular players. According to the current model, binding of Izumo and Juno induces accumulation ofCD9 in the contact area and thereby promotes $\mathrm{CD} 9$-mediated clustering of the membrane proteins that participate in the assembly of putative fusion machinery $[76,78]$. The current goal for researchers is to identify the crucial fusion-inducing component of this machinery.

The nature of Izumo-Juno interaction was found to be conserved in several mammalian species including humans [77]. Normally, the ZP establishes interspecies reproductive isolation. But at the absence of the protective layer, certain orthologues of Izumo and Juno proteins may directly interact allowing for cross-species gamete fusion in vitro. In particular, it has been demonstrated that mouse Izumo is capable of inducing 
adhesion with the human egg membrane [75]. Further, the recombinanat hamster Juno can bind human, mouse, and pig Izumo whereas human Izumo interacts with hamster but not mouse Juno [84]. This data provides a molecular explanation for a long-recognized ability of acrosome-reacted human sperms to penetrate zona-free hamster eggs. The phenomenon of heterologous fusion can be clinically exploited to assess the human sperm fertilizing capacity in vitro [85]. Due to the identification of surface proteins, vital for sperm-egg interaction, it may now be possible to develop better diagnostic assays, sperm selection techniques, and a new generation of contraceptives. It would be also interesting to investigate whether the altered expression of and/or misrecognition of key fertilization receptors contributes to human idiopathic infertility and unexplained fertilization failure.

\section{Egg activation}

Following their fusion with sperm, mammalian oocytes undergo periodic changes in cytosolic $\mathrm{Ca}^{2+}$ concentration, referred to as "calcium oscillations." $\mathrm{Ca}^{2+}$ transients orchestrate a sequence of events involving the establishment of a block to polyspermy, liberation from metaphase II arrest, selective recruitment and degradation of maternal mRNA, pronuclear development, and initiation of embryonic gene expression. This process is collectively termed as "oocyte activation" and marks the transition from a gamete into an embryo. The nature, amplitude, duration, and frequency of the calcium oscillations are species-specific. In humans, this physiological signal lasts several hours and the profile of $\mathrm{Ca}^{2+}$ spikes appear to be related to embryo developmental competence [86-88]. Calcium imaging studies of eggs inseminated in vitro showed that the first wave of $\mathrm{Ca}^{2+}$ oscillations begins at sperm entry and spreads as a radial wave towards the opposite egg pole [89]. The finding that the injection of cytosolic sperm extract evokes characteristic $\mathrm{Ca}^{2+}$ oscillations implied that egg activation is triggered by a soluble factor delivered by the fertilizing spermatozoon [90-92]. It was hypothesized that the sperm-borne oocyte activation factor (SOAF) is released from perinuclear theca, a cytoskeletal coat over sperm head which dissolves concomitantly with sperm nuclear decondensation. SOAF then diffuses in ooplasm and triggers signaling cascade of oocyte activation via the coordinated release of $\mathrm{Ca}^{2+}$ from oocyte the endoplasmic reticulum stores. Interestingly, oocyte activation after ICSI occurs only when perinuclear theca of an injected spermatozoon is dissolved [93].

Various sperm proteins were evaluated for their ability to induce rises of $\left[\mathrm{Ca}^{2+}\right] \mathrm{i}$ and activate the egg [94-98]. Among them, the testes-specific isoform of phospholipase $\mathrm{C}$, named PLC zeta, has been put forward as the strongest candidate for the long-sought-after soluble SOAF $[99,100]$. Several lines of evidence from independent laboratories accumulated over the years supporting the contention that PLC zeta represents a physiological agent responsible for generating $\mathrm{Ca}^{2+}$ oscillations and triggering embryogenesis in mammals [87, 101]. This cytosolic sperm protein is introduced into the oocyte upon sperm entry, interacts with the yet-to-be-identified oocyte factor(s), and evokes the characteristic pattern of serial $\mathrm{Ca}^{2+}$ release in ooplasm [88]. Sperm with impaired expression of PLC zeta have reduced or absent capacity to elicit $\mathrm{Ca}^{2+}$ oscillations in the egg $[102,103]$. The egg activation can be achieved in the absence of sperm by microinjection of mouse/human PLC zeta which induces fertilization-like $\mathrm{Ca}^{2+}$ signal and has the potential to trigger parthenogenetic embryo development $[99,100$, 104-106]. Besides, cumulative clinical data suggests that PLC zeta deficiency contributes towards male and idiopathic infertility. Particularly cases with recurrent fertilization failure seem to be intimately linked with the function of PLC zeta [105, 107, 108].

The current tools to evaluate the fertilizing capacity of the sperm are restricted to the mouse oocyte activation test (MOAT). This test categorizes male patients according to the ability of their sperm to activate mouse oocyte development $[109,110]$. When a high activation rate is detected by MOAT, the sperm-related problem is ruled out and oocyte factors are suspected to account for fertilization failure. However, a large volume of human oocyte represents a greater challenge for activation than a mouse oocyte. This is consistent with the finding that the human sperm contains a more potent variant of PLC zeta which can trigger $\mathrm{Ca}^{2+}$ oscillations in a lower concentration than the mouse enzyme [111]. It is thus possible that PLC zeta-deficient human spermatozoa, incapable of fertilizing human eggs, are still able to activate a smaller mouse oocyte. Due to the interspecies differences in the intrinsic activity of the key fertilization enzyme, the test employing heterologous mousehuman model has only limited diagnostic value. Besides, practical and legal restrictions concerning cross-species fertilization in many countries hinder the wide application of MOAT in clinical practice. There is much interest in developing a sensitive and robust prognostic assay for sperm activation potency. Implementing evaluation of PLC zeta function in clinical settings would enable appropriate management of the fertility treatment.

At present, assisted oocyte activation (AOA) is the only therapeutical option available for patients experiencing total fertilization failure following ICSI. However, in vitro treatment with calcium ionophores (e.g., calcimycin and ionomycin) does not induce repetitive $\mathrm{Ca}^{2+}$ oscillations. Instead, it leads to a steady increase of $\left[\mathrm{Ca}^{2+}\right]$ i which might facilitate spontaneous activation in the absence of sperm. Moreover, exposure of the oocytes to both agents raises serious concerns regarding a long-term epigenetic effect of the non-physiological stimuli on the development of the resulting embryo [112]. Some research investigated the 
possibility of using a combination of ICSI with direct microinjection of PLC zeta protein or complementary RNA as an alternative to controversial AOA [106, 113]. Although current results are very promising, well-designed clinical studies are needed to confirm that PLC zeta indeed constitutes a "magic bullet" that would rescue the fertilization failure caused by the sperm factor before the method can be safely translated to clinical practice. Research should also focus on the molecular cascade triggered by PLC zeta following gamete fusion. It would be beneficial to identify the oocyte proteins contributing to activation deficiency as these molecules may also represent useful diagnostic and therapeutical targets [88].

\section{Block to polyspermy}

The basic prerequisite for successful conception is that an egg is fertilized by a single sperm only. The presence of more than one male nucleus inside of the female gamete would cause severe genetic imbalance in the resulting embryo. To ensure monospermic fertilization, the oocytes evolved the series of safety mechanisms to avoid additional sperm fusion events, collectively referred to as a "polyspermy block" (Fig. 2). The entry of multiple spermatozoa is prevented by modification of the oolemma and egg vestments with the relative importance of these protective barriers varying among species [114].

\section{Membrane depolarization}

The membrane block to polyspermy was intensively studied in marine animals. The experiments showed that the attachment of the first sperm induces a rapid shift in the egg membrane potential from negative to positive level [115]. This alteration of the electric charge hinders other sperm attachment to the oocyte surface. This observation led to the conclusion that postfertilization membrane depolarization represents a fast block to polyspermy. Although commonly referred to as an evolutionarily conserved safeguard response, the contribution of an electrically mediated membrane block is virtually unfounded in mammals, including humans. It is likely that here, the fast membrane depolarization is less important than in invertebrates and amphibians because the female reproductive tract limits arrival of the sperm to the fertilization site and the sperm-to-egg ratio is thus much lower than during external fertilization $[116,117]$. Besides, the membrane potential overshot is only transient, lasting up to several minutes. To establish an effective barrier to secondary fertilization, the short-acting electrical depolarization must be complemented by a permanent block.

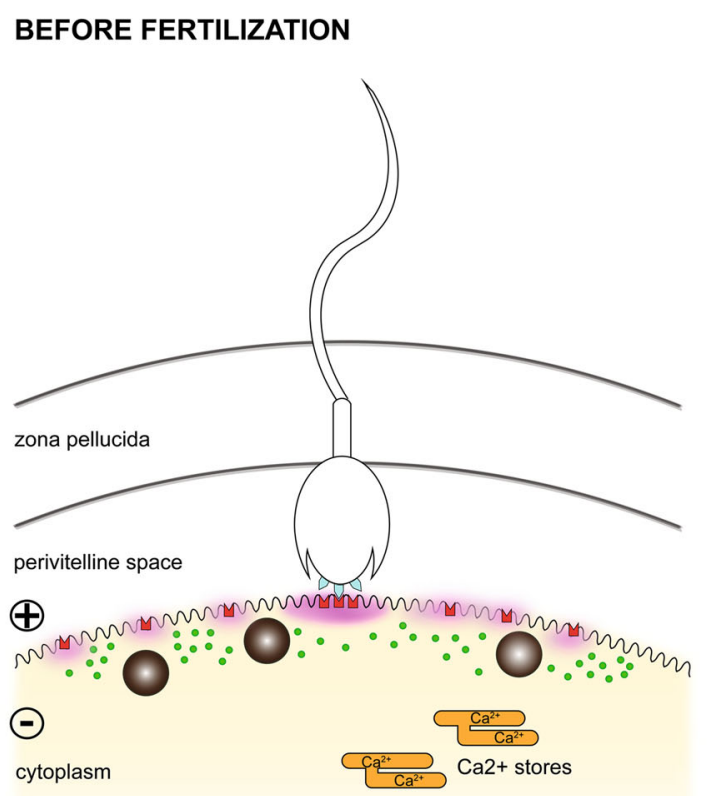

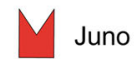

uno
Izumo

CD9

Fig. 2 The mechanisms of prevention against polyspermy. Upon fertilization oocyte membrane becomes unreceptive to further sperm binding by 1) membrane depolarization and 2) removal of oocyte

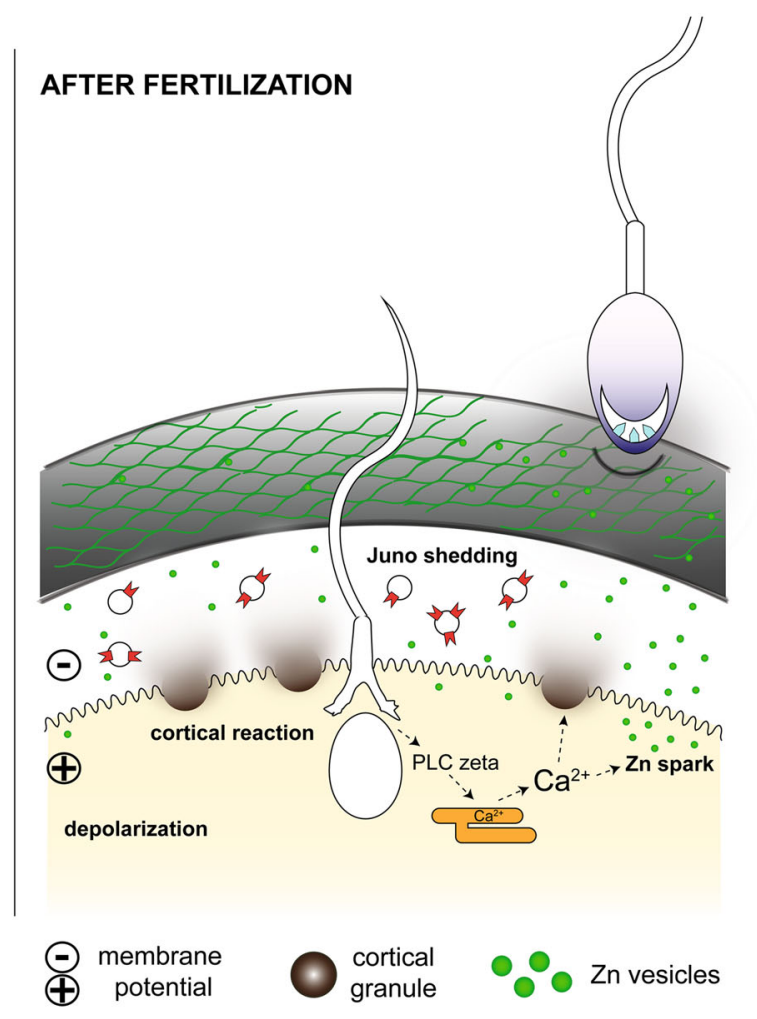

receptor Juno from oolemma. A permanent mechanical block is established with 3) cortical reaction and 4) Zn spark-induced hardening of the zona pellucida 


\section{Juno removal}

An alternative mechanism for the establishment of a fast membrane block against polyspermy has been proposed. When investigating molecular details of the gamete fusion process in mice, Bianchi and colleagues observed that after the initial Izumo-Juno contact was established, remaining oocyte receptors were shed off the egg membrane within extracellular vesicles [76]. Rapid loss of Juno from the oocyte surface renders the already fertilized egg refractory to additional sperm binding. The authors speculated that the presence of the Junocontaining vesicles in the perivitelline space might also serve as a "decoy" which neutralizes incoming spermatozoa and prevents secondary fertilization. Interestingly, when gamete recognition was circumvented by ICSI, Juno was not removed from the oocyte surface and the egg remained receptive to further sperm [78]. This finding is consistent with previous observations that ICSI does not induce an effective block to polyspermy in mammalian eggs $[118,119]$. Studies are being undertaken to provide the evidence that the removal of Juno from egg s surface contributes to the establishment of a polyspermy block in humans.

\section{Cortical reaction}

The most studied strategy on how to reduce the incidence of polyspermy is the slow mechanical block at the level of the egg s external coat. Once the egg is fertilized, the surrounding ZP becomes impermeable to late-coming sperm. Although molecular details of this process remain unclear, the crucial role of cortical granules (CGs) has been recognized. These membrane-bound secretory organelles are derived from the Golgi apparatus early in development [120] and during oocyte maturation, they progressively translocate towards the periphery in an actin-dependent manner [121]. In the periovulatory egg, the electron-dense CGs are densely aligned underneath the oocyte cortex, hence the name "cortical granules" [120, 122]. The oocyte activation following the first sperm penetration evokes $\mathrm{Ca}^{2+}$ oscillations which in turn trigger CG exocytosis, known as a "cortical reaction." The fusion of CGs with the plasma membrane leads to a burst of their content into the perivitelline space. The released proteins cause a structural modification of ZP that slowly transforms the receptive outer coat of the oocyte to the hardened protective layer of the developing embryo [123]. Post-fertilization aging of the oocyte creates the risk that cortical reaction is triggered spontaneously without fertilization. Premature or partial exocytosis of CGs compromises the effectiveness of the ZP block and contributes to a high incidence of abnormal fertilization in aged oocytes [124].

Until recently, the content of CGs has been largely unknown. The identification of mouse ovastacin has shed light on mechanistic bases of the zona hardening process. This protease is discharged from CGs and cleaves glycoprotein $\mathrm{ZP}$, a building component of the ZP. The destruction of the primary sperm binding ligand in the zona matrix establishes a definite post-fertilization block to polyspermy. The role of ovastacin was supported by the finding that in ovastacindeficient female mice, ZP2 remains intact after fertilization and sperm bind even to 2-cell stage embryos [125, 126]. Recent research revealed that the slow block to polyspermy is further regulated on a higher level. It has been shown that, in mouse oocytes, $\mathrm{CG}$ exocytosis is prevented by the abundance of a liver-derived plasma protein fetuin [127]. In 2013, Dietzel and colleagues took advantage of targeted gene depletion and mouse transplantation experiments to demonstrate that a member of the fetuin family, fetuin B, controls ovastacin activity. This study concluded that fetuin B is required to specifically inactivate traces of ovastacin constantly leaking from unfertilized oocytes [128]. In other words, the direct inhibition by fetuin-B restrains basal ovastacin activity and keeps the ovulated egg fertilizable. However, once a sperm has penetrated, the oocyte s cortical reaction is unleashed, and ovastacin surge will overwhelm the fetuin-B buffer capacity, thereby initiating the zona hardening. The finding that fertilization can be controlled by a liver-derived plasma protein demonstrates extreme complexity of the regulatory circuits orchestrating mammalian fecundity. Based on the mice data, the authors proposed that the addition of exogenous fetuin-B into the oocyte culture media might increase in vitro fertilization (IVF) success in humans [129]. So far, only two clinical studies assessed the association between the level of fetuin-B and fertilization rate in human IVF patients. Both showed that serum fetuin B level can serve as a predictive marker which may help to make an informed decision whether the oocytes should be fertilized by conventional IVF or ICSI that overcomes the ZP barrier [130, 131]. Moreover, it has been reported that pharmacological down-regulation of fetuin-B caused reversible infertility in female mice [132] suggesting that this blood protein might represent a molecular target for the development of novel therapies for short-term modulation of female fertility. Although the current experimental data is very promising, more clinical studies performed by independent research groups are warranted to confirm the role of fetuin-B human reproductive biology.

\section{Zinc spark}

During the last decade, zinc ( $\mathrm{Zn})$ has emerged as another essential element in ensuring monospermic fertilization. The work of Woodruff and colleagues has advanced our knowledge of the role of $\mathrm{Zn}$ in mammalian reproduction. In a series of experimental studies, the researchers used a combination of imaging and biochemical tools to study the $\mathrm{Zn}$ dynamics in mammalian oocytes before and after fertilization [133-139]. Selective $\mathrm{Zn}$ indicators revealed that intracellular $\mathrm{Zn}$ 
concentration extensively increases during oocyte maturation and its localization tracks show similar pattern to CGs staining. Accumulation of $\mathrm{Zn}$ is a physiological imperative to avoid a premature exit from meiosis and sustain metaphase II arrest. On the contrary, the rapid loss of $\mathrm{Zn}$ at the time of fertilization is required for the egg-to-embryo transition [134, 137]. Explosive Zn efflux immediately following sperm entry has been visualized by a vital fluorogenic zinc probe [136, 137]. Due to the characteristic radial glare pattern of an activated egg, this phenomenon has gained the name a "zinc spark." Apart from being an early hallmark of successful fertilization, the serial exocytosis of $\mathrm{Zn}$-containing vesicles contributes to the $\mathrm{ZP}$ hardening. The released metal ions execute their role differently than proteases stored in the CGs. Instead of cleaving glycoproteins of the ZP, exposure to $\mathrm{Zn}$ alters the architecture of the egg s outer layer by stabilizing glycoprotein chains and bundling fibril components of the extracellular matrix. Conformational change turns ZP into a stiff mechanical barrier that obstructs further sperm access to the already fertilized egg [138]. The massive increase of extracellular $\mathrm{Zn}$ concentration establishes a "zinc shield" which could derail $\mathrm{Zn}$ signaling in late-coming spermatozoa thus adding a further component to anti-polyspermy defense [140].

The fertilization-induced zinc spark appears to be evolutionary conserved across mammalian species [133, 136, 137]. In mice, the amount of $\mathrm{Zn}$ released at the time of fertilization correlates with successful embryo development to the blastocyst stage [136]. This finding raises the intriguing option to develop the platform to quantify the zinc spark in humans. Non-invasive measurement of extracellular $\mathrm{Zn}$ in the culture medium would enable prospective selection of the best quality embryos for fertility treatment. Besides, the early detection of activation failure in oocytes conventionally inseminated in vitro would leave the opportunity to perform rescue ICSI during routine working hours. This approach would aid in the prevention of the overuse of ICSI in clinical practice. Furthermore, experimental treatment with $\mathrm{Zn}$-specific chelator demonstrated that reduction of intracellular $\mathrm{Zn}$ is sufficient to induce human egg activation [137]. As shown in the porcine system, this kind of treatment may increase the efficacy of AOA, particularly in calcium ionophore-resistant cases $[141,142]$. New findings regarding the $\mathrm{Zn}$ role in reproduction should be taken into consideration in search of optimal conditions for in vitro maturation (IVM) of human oocytes. It has been shown that supplementation of IVM media with adequate $\mathrm{Zn}$ concentration improved maturation and developmental potential of porcine oocytes. It would be interesting to examine if such treatment could also enhance cytoplasmic maturation and fertilization rate of oocytes in human IVM cycles [143].

There are still many unanswered questions regarding strategies mammalian eggs use to reduce the risk of multiple sperm penetration. Future studies might bring new revelations showing that the process is more complex than previously acknowledged. Yet, the importance of the polyspermy block in mammals is being disputed by some researchers who are raising concerns regarding the relevance of research data from in vitro inseminations. They point out that, in vivo, the female reproduction tract greatly limits the number of sperm reaching the fertilization site, thus reducing the risk of simultaneous fertilization. But, under laboratory conditions, high rates of polyspermy are artificially induced by increasing the sperm concentration [144]. Therefore, the experiments involving oocytes deprived of their vestments or exposed to an unnaturally high number of spermatozoa might be unrepresentative for the physiological situation and must be interpreted with caution [117].

Although most embryos inheriting an extra set of chromosomes die during the cleavage stage, some can give rise to a viable blastocyst and survive into gestation. Based on cytogenetic studies performed on spontaneous abortions, polyspermy is estimated to account for $2-3 \%$ of natural pregnancies [114, 145-148]. However, the actual incidence of this phenomenon might be underreported since, in vivo, arrest in preimplantation development, implantation failure, and early pregnancy loss goes unnoticed. Interestingly, some cases of atypical twinning have been attributed to the dispermic fertilization [149-151]. Detailed genotyping implicated the double sperm penetration in the case of live-born monochorionic but sex-discordant twins. The pair shared $78 \%$ of their parental genome while maternally derived genetic information was identical. This "sesquizygosity" is thought to arise from heterogoneic assortment of paternal genomes following fertilization of a single egg by two spermatozoa [151].

\section{Future perspectives}

Conception is the most intimate moment of our lives. Although being of great scientific and clinical relevance, understanding of the molecular basis of fertilization remains rudimentary. Most of what we know about sperm-oocyte interaction stems from animal studies. The development of IVF methods offered a simplified functional assay to study mechanistic and molecular aspects of the mammalian fertilization in laboratory conditions. Furthermore, the ability to create genedeficient "knockout" mice permitted us to assess the in vivo relevance of molecules implicated in gamete recognition [47]. However, extrapolating research results from animals to humans is problematic due to interspecific differences in reproduction and fertility. The paucity of scientific knowledge about human fertilization is largely attributed to a unique nature and heterogeneity of gametes which are extremely difficult to be experimentally manipulated. The procurement of human oocytes for research purposes is limited to only a small number of surplus oocytes rejected for fertility treatment. Apart from that, the research that brings human eggs and 
sperm together in the same dish is forbidden in most countries. The stakeholders' agreement of ethical acceptance of experiments involving coincubation of human gametes would stimulate the research in this field. Alternatively, development of fully functional human gametes in vitro using genetic reprogramming or differentiation from human embryonic stem cells would help to bypass ethical and legal restrictions [152].

There are powerful genomic, imaging, and analytical tools available to study the delicate sperm-egg dialogue. Technical advancements now enable in-depth whole-genome, transcriptome, proteome, and secretome profiling of single cells. Until recently, the loss-of-function assays in human gametes were virtually impossible. However, the revolutionary geneediting technique opens a new area of research allowing researchers to dissect the role of individual molecules in the process of gamete recognition and fusion [153]. The recently developed Trim-Away method for acute and rapid degradation of endogenous proteins provides the opportunity to assess the requirement of a selected molecular candidate for fertilization competence in human oocytes [154, 155]. These targeting approaches offer an elegant alternative to immunological techniques and non-specific pharmacological interventions. In addition, the potential of cell-penetrating peptides (CPP) to deliver selected bioactive moieties across the plasma membrane has been investigated in various cells, including bovine and human sperm $[156,157]$. The experimental data suggest that CPP can traffic small regulatory proteins and thus directly influence sperm physiology including progesterone-induced hyperactivation. The idea to temporarily halt sperm motility either by CPP or small-molecular inhibitors interfering with the CatSper function is very appealing to the pharmaceutical industry. However, controlling millions of sperm poses an enormous challenge as opposed to the ovulation of a single egg. Clinical trials assessing efficiency and safety are essential before the concept of a male pill can be marketed. The search for birth control agents centers on the Juno and Izumo interaction. The crystallographic study which determined structure of these receptors represents a necessary stepping stone towards a rational design of a drug which would act as a short-acting non-hormonal contraceptive [158].

There is another good reason to investigate the sex cell interaction. Unveiling the secrets of human fertilization might bring new therapeutic options for millions of patients suffering from infertility. The identification of molecules that are pivotal for sperm functionality and interaction with the egg paves the way for the development of innovative diagnostic tools and biomarker-based assays for the selection of fertilization-competent gametes in human IVF. Although the translation of scientific discoveries to improved healthcare is generally slow, current findings might soon find practical application in reproductive medicine. Particularly the combination the functional tests with microfluidics holds potential to simulate natural selection occurring in vivo. By increasing our knowledge of human procreation, in the future, certain fertility issues may be treatable or even cured, for example, by stimulating relevant signaling pathways or by genetic therapy, rather than bypassing them with ICSI.

Funding information Work of our lab is supported by the Neuron Fund for Support of Science and the Czech Science Foundation (GJ 1914990Y).

\section{Compliance with ethical standards}

Conflict of interests The authors declare that they have no conflict of interest.

Open Access This article is licensed under a Creative Commons Attribution 4.0 International License, which permits use, sharing, adaptation, distribution and reproduction in any medium or format, as long as you give appropriate credit to the original author(s) and the source, provide a link to the Creative Commons licence, and indicate if changes were made. The images or other third party material in this article are included in the article's Creative Commons licence, unless indicated otherwise in a credit line to the material. If material is not included in the article's Creative Commons licence and your intended use is not permitted by statutory regulation or exceeds the permitted use, you will need to obtain permission directly from the copyright holder. To view a copy of this licence, visit http://creativecommons.org/licenses/by/4.0/.

\section{References}

1. Sakkas D, Ramalingam M, Garrido N, Barratt CL. Sperm selection in natural conception: what can we learn from Mother Nature to improve assisted reproduction outcomes? Hum Reprod Update. 2015;21(6):711-26.

2. Aitken RJ, Nixon B. Sperm capacitation: a distant landscape glimpsed but unexplored. Mol Hum Reprod. 2013;19(12):78593.

3. Puga Molina LC, Luque GM, Balestrini PA, Marin-Briggiler CI, Romarowski A, Buffone MG. Molecular basis of human sperm capacitation. Front Cell Dev Biol. 2018;6:72.

4. Suarez SS. Formation of a reservoir of sperm in the oviduct. Reprod Domest 4 Anim. 2002;37(3):140-143.

5. Wang S, Larina IV. In vivo three-dimensional tracking of sperm behaviors in the mouse oviduct. Development. 2018;145(6).

6. Bannai H, Yoshimura M, Takahashi K, Shingyoji C. Calcium regulation of microtubule sliding in reactivated sea urchin sperm flagella. J Cell Sci. 2000;113(Pt 5):831-9.

7. Ho HC, Granish KA, Suarez SS. Hyperactivated motility of bull sperm is triggered at the axoneme by $\mathrm{Ca} 2+$ and not cAMP. Dev Biol. 2002;250(1):208-17.

8. Carlson AE, Westenbroek RE, Quill T, et al. CatSper1 required for evoked $\mathrm{Ca} 2+$ entry and control of flagellar function in sperm. Proc Natl Acad Sci U S A. 2003;100(25):14864-8.

9. Kirichok Y, Navarro B, Clapham DE. Whole-cell patch-clamp measurements of spermatozoa reveal an alkaline-activated $\mathrm{Ca} 2+$ channel. Nature. 2006;439(7077):737-40.

10. Chung JJ, Miki K, Kim D, et al. CatSperzeta regulates the structural continuity of sperm $\mathrm{Ca}(2+)$ signaling domains and is required for normal fertility. elife. 2017;6:e23082.https://elifesciences.org/ articles $/ 23082$ 
11. Qi H, Moran MM, Navarro B, Chong JA, Krapivinsky G, Krapivinsky L, et al. All four CatSper ion channel proteins are required for male fertility and sperm cell hyperactivated motility. Proc Natl Acad Sci U S A. 2007;104(4):1219-23.

12. Ren D, Navarro B, Perez G, Jackson AC, Hsu S, Shi Q, et al. A sperm ion channel required for sperm motility and male fertility. Nature. 2001;413(6856):603-9.

13. Bystroff $C$. Intramembranal disulfide cross-linking elucidates the super-quaternary structure of mammalian CatSpers. Reprod Biol. 2018;18(1):76-82.

14. Singh AP, Rajender S. CatSper channel, sperm function and male fertility. Reprod BioMed Online. 2015;30(1):28-38.

15. Hildebrand MS, Avenarius MR, Fellous M, Zhang Y, Meyer NC, Auer J, et al. Genetic male infertility and mutation of CATSPER ion channels. Eur J Hum Genet. 2010;18(11):1178-84.

16. Visser L, Westerveld GH, Xie F, et al. A comprehensive gene mutation screen in men with asthenozoospermia. Fertil Steril. 2011;95(3):1020-4 e1021-1029.

17. Bhilawadikar R, Zaveri K, Mukadam L, Naik S, Kamble K, Modi $\mathrm{D}$, et al. Levels of Tektin 2 and CatSper 2 in normozoospermic and oligoasthenozoospermic men and its association with motility, fertilization rate, embryo quality and pregnancy rate. J Assist Reprod Genet. 2013;30(4):513-23.

18. Smith JF, Syritsyna O, Fellous M, Serres C, Mannowetz N, Kirichok Y, et al. Disruption of the principal, progesteroneactivated sperm $\mathrm{Ca} 2+$ channel in a CatSper2-deficient infertile patient. Proc Natl Acad Sci U S A. 2013;110(17):6823-8.

19. Williams HL, Mansell S, Alasmari W, Brown SG, Wilson SM, Sutton KA, et al. Specific loss of CatSper function is sufficient to compromise fertilizing capacity of human spermatozoa. Hum Reprod. 2015;30(12):2737-46.

20. Suarez SS. Control of hyperactivation in sperm. Hum Reprod Update. 2008;14(6):647-57.

21. Windler F, Bonigk W, Korschen HG, et al. The solute carrier SLC9C1 is a $\mathrm{Na}(+) / \mathrm{H}(+)$-exchanger gated by an S4-type voltage-sensor and cyclic-nucleotide binding. Nat Commun. 2018;9(1):2809.

22. Hwang JY, Mannowetz N, Zhang Y, Everley RA, Gygi SP, Bewersdorf J, et al. Dual sensing of physiologic $\mathrm{pH}$ and calcium by EFCAB9 regulates sperm motility. Cell. 2019;177(6):1480-94 e1419.

23. Maas DH, Storey BT, Mastroianni L Jr. Hydrogen ion and carbon dioxide content of the oviductal fluid of the rhesus monkey (Macaca mulatta). Fertil Steril. 1977;28(9):981-5.

24. Lishko PV, Botchkina IL, Kirichok Y. Progesterone activates the principal Ca2+ channel of human sperm. Nature. 2011;471(7338): 387-91.

25. Strunker T, Goodwin N, Brenker C, et al. The CatSper channel mediates progesterone-induced $\mathrm{Ca} 2+$ influx in human sperm. Nature. 2011;471(7338):382-6.

26. Teves ME, Barbano F, Guidobaldi HA, Sanchez R, Miska W, Giojalas LC. Progesterone at the picomolar range is a chemoattractant for mammalian spermatozoa. Fertil Steril. 2006;86(3):745-9.

27. Miller MR, Mannowetz N, Iavarone AT, Safavi R, Gracheva EO, Smith JF, et al. Unconventional endocannabinoid signaling governs sperm activation via the sex hormone progesterone. Science. 2016;352(6285):555-9.

28. Cai X, Clapham DE. Evolutionary genomics reveals lineagespecific gene loss and rapid evolution of a sperm-specific ion channel complex: CatSpers and CatSperbeta. PLoS One. 2008;3(10):e3569.

29. Rahman MS, Kwon WS, Pang MG. Calcium influx and male fertility in the context of the sperm proteome: an update. Biomed Res Int. 2014;2014:841615.
30. Brenker C, Goodwin N, Weyand I, Kashikar ND, Naruse M, Krähling $\mathrm{M}$, et al. The CatSper channel: a polymodal chemosensor in human sperm. EMBO J. 2012;31(7):1654-65.

31. Li H, Ding X, Guan H, Xiong C. Inhibition of human sperm function and mouse fertilization in vitro by an antibody against cation channel of sperm 1: the contraceptive potential of its transmembrane domains and pore region. Fertil Steril. 2009;92(3): 1141-6.

32. Li H, Ding X, Guo C, Guan H, Xiong C. Immunization of male mice with B-cell epitopes in transmembrane domains of CatSper1 inhibits fertility. Fertil Steril. 2012;97(2):445-52.

33. Carlson AE, Burnett LA, del Camino D, et al. Pharmacological targeting of native CatSper channels reveals a required role in maintenance of sperm hyperactivation. PLoS One. 2009;4(8): e6844.

34. Mannowetz N, Miller MR, Lishko PV. Regulation of the sperm calcium channel CatSper by endogenous steroids and plant triterpenoids. Proc Natl Acad Sci U S A. 2017;114(22):5743-8.

35. Tavares RS, Mansell S, Barratt CL, Wilson SM, Publicover SJ, Ramalho-Santos J. p,p'-DDE activates CatSper and compromises human sperm function at environmentally relevant concentrations. Hum Reprod. 2013;28(12):3167-77.

36. Schiffer C, Muller A, Egeberg DL, et al. Direct action of endocrine disrupting chemicals on human sperm. EMBO Rep. 2014;15(7): 758-65.

37. Rehfeld A, Dissing S, Skakkebaek NE. Chemical UV filters mimic the effect of progesterone on $\mathrm{Ca}(2+)$ signaling in human sperm cells. Endocrinology. 2016;157(11):4297-308.

38. He Y, Zou Q, Li B, Chen H, du X, Weng S, et al. Ketamine inhibits human sperm function by $\mathrm{Ca}(2+)$-related mechanism. Biochem Biophys Res Commun. 2016;478(1):501-6.

39. Shannon M, Rehfeld A, Frizzell C, et al. In vitro bioassay investigations of the endocrine disrupting potential of steviol glycosides and their metabolite steviol, components of the natural sweetener Stevia. Mol Cell Endocrinol. 2016;427:65-72.

40. Zou QX, Peng Z, Zhao Q, Chen HY, Cheng YM, Liu Q, et al. Diethylstilbestrol activates CatSper and disturbs progesterone actions in human spermatozoa. Hum Reprod. 2017;32(2):290-8.

41. Brenker C, Schiffer C, Wagner IV, et al. Action of steroids and plant triterpenoids on CatSper $\mathrm{Ca}(2+)$ channels in human sperm. Proc Natl Acad Sci U S A. 2018;115(3):E344-6.

42. Costello S, Michelangeli F, Nash K, Lefievre L, Morris J, Machado-Oliveira G, et al. Ca2+-stores in sperm: their identities and functions. Reproduction. 2009;138(3):425-37.

43. Correia J, Michelangeli F, Publicover S. Regulation and roles of $\mathrm{Ca} 2+$ stores in human sperm. Reproduction. 2015;150(2):R6576.

44. Alasmari W, Costello S, Correia J, Oxenham SK, Morris J, Fernandes L, et al. Ca2+ signals generated by CatSper and $\mathrm{Ca} 2+$ stores regulate different behaviors in human sperm. J Biol Chem. 2013;288(9):6248-58.

45. Stein KK, Primakoff P, Myles D. Sperm-egg fusion: events at the plasma membrane. J Cell Sci. 2004;117(Pt 26):6269-74.

46. Sutovsky P. Sperm-egg adhesion and fusion in mammals. Expert Rev Mol Med. 2009;11:e11.

47. Ikawa M, Inoue N, Benham AM, Okabe M. Fertilization: a sperm's journey to and interaction with the oocyte. J Clin Invest. 2010;120(4):984-94.

48. Bianchi E, Wright GJ. Sperm meets egg: the genetics of mammalian fertilization. Annu Rev Genet. 2016;50:93-111.

49. Wilson NF, Snell WJ. Microvilli and cell-cell fusion during fertilization. Trends Cell Biol. 1998;8(3):93-6.

50. Speksnijder JE, Jaffe LF, Sardet C. Polarity of sperm entry in the ascidian egg. Dev Biol. 1989;133(1):180-4. 
51. Motosugi N, Dietrich JE, Polanski Z, Solter D, Hiiragi T. Space asymmetry directs preferential sperm entry in the absence of polarity in the mouse oocyte. PLoS Biol. 2006;4(5):e135.

52. Hosseini SM, Moulavi F, Tanhaie-Vash N, Asgari V, Ghanaei HR, Abedi-Dorche M, et al. The principal forces of oocyte polarity are evolutionary conserved but may not affect the contribution of the first two blastomeres to the blastocyst development in mammals. PLoS One. 2016;11(3):e0148382.

53. Phillips DM, Shalgi R. Surface architecture of the mouse and hamster zona pellucida and oocyte. J Ultrastruct Res. 1980;72(1):1-12.

54. Talansky BE, Malter HE, Cohen J. A preferential site for spermegg fusion in mammals. Mol Reprod Dev. 1991;28(2):183-8.

55. Santella L, Alikani M, Talansky BE, Cohen J, Dale B. Is the human oocyte plasma membrane polarized? Hum Reprod. 1992;7(7):999-1003.

56. Van Blerkom J, Caltrider K. Sperm attachment and penetration competence in the human oocyte: a possible aetiology of fertilization failure involving the organization of oolemmal lipid raft microdomains influenced by the DeltaPsim of subplasmalemmal mitochondria. Reprod BioMed Online. 2013;27(6):690-701.

57. Okabe M. The cell biology of mammalian fertilization. Development. 2013;140(22):4471-9.

58. Runge KE, Evans JE, He ZY, Gupta S, McDonald K, Stahlberg H, et al. Oocyte CD9 is enriched on the microvillar membrane and required for normal microvillar shape and distribution. Dev Biol. 2007;304(1):317-25.

59. Chen MS, Tung KS, Coonrod SA, Takahashi Y, Bigler D, Chang $A$, et al. Role of the integrin-associated protein CD9 in binding between sperm ADAM 2 and the egg integrin alpha6beta1: implications for murine fertilization. Proc Natl Acad Sci U S A. 1999;96(21):11830-5.

60. Kaji K, Oda S, Shikano T, Ohnuki T, Uematsu Y, Sakagami J, et al. The gamete fusion process is defective in eggs of Cd9deficient mice. Nat Genet. 2000;24(3):279-82.

61. Le Naour F, Rubinstein E, Jasmin C, Prenant M, Boucheix C. Severely reduced female fertility in CD9-deficient mice. Science. 2000;287(5451):319-21.

62. Miyado K, Yamada G, Yamada S, Hasuwa H, Nakamura Y, Ryu F, et al. Requirement of CD9 on the egg plasma membrane for fertilization. Science. 2000;287(5451):321-4.

63. Jegou A, Ziyyat A, Barraud-Lange V, et al. CD9 tetraspanin generates fusion competent sites on the egg membrane for mammalian fertilization. Proc Natl Acad Sci U S A. 2011;108(27):1094651.

64. Barraud-Lange V, Naud-Barriant N, Bomsel M, Wolf JP, Ziyyat A. Transfer of oocyte membrane fragments to fertilizing spermatozoa. FASEB J. 2007;21(13):3446-9.

65. Miyado K, Yoshida K, Yamagata K, Sakakibara K, Okabe M, Wang X, et al. The fusing ability of sperm is bestowed by CD9containing vesicles released from eggs in mice. Proc Natl Acad Sci U S A. 2008;105(35):12921-6.

66. Inoue $\mathrm{N}$, Ikawa $\mathrm{M}$, Isotani $\mathrm{A}$, Okabe $\mathrm{M}$. The immunoglobulin superfamily protein Izumo is required for sperm to fuse with eggs. Nature. 2005;434(7030):234-8.

67. Satouh Y, Inoue N, Ikawa M, Okabe M. Visualization of the moment of mouse sperm-egg fusion and dynamic localization of IZUMO1. J Cell Sci. 2012;125(Pt 21):4985-90.

68. Spiridonov NA, Wong L, Zerfas PM, Starost MF, Pack SD, Paweletz CP, et al. Identification and characterization of SSTK, a serine/threonine protein kinase essential for male fertility. Mol Cell Biol. 2005;25(10):4250-61.

69. Sosnik J, Miranda PV, Spiridonov NA, Yoon SY, Fissore RA, Johnson GR, et al. Tssk6 is required for Izumo relocalization and gamete fusion in the mouse. J Cell Sci. 2009;122(Pt 15): 2741-9.
70. Clark S, Naz RK. Presence and incidence of izumo antibodies in sera of immunoinfertile women and men. Am J Reprod Immunol. 2013;69(3):256-63.

71. Granados-Gonzalez V, Aknin-Seifer I, Touraine RL, Chouteau J, Wolf JP, Levy R. Preliminary study on the role of the human IZUMO gene in oocyte-spermatozoa fusion failure. Fertil Steril. 2008;90(4):1246-8.

72. Hayasaka S, Terada Y, Inoue N, Okabe M, Yaegashi N, Okamura K. Positive expression of the immunoglobulin superfamily protein IZUMO on human sperm of severely infertile male patients. Fertil Steril. 2007;88(1):214-6.

73. Naz RK. Immunocontraceptive effect of Izumo and enhancement by combination vaccination. Mol Reprod Dev. 2008;75(2):33644.

74. Wang M, Lv Z, Shi J, Hu Y, Xu C. Immunocontraceptive potential of the Ig-like domain of Izumo. Mol Reprod Dev. 2009;76(8): 794-801.

75. Naz RK. Vaccine for human contraception targeting sperm Izumo protein and YLP12 dodecamer peptide. Protein Sci. 2014;23(7): 857-68.

76. Chalbi M, Barraud-Lange V, Ravaux B, Howan K, Rodriguez N, Soule $\mathrm{P}$, et al. Binding of sperm protein Izumol and its egg receptor Juno drives Cd9 accumulation in the intercellular contact area prior to fusion during mammalian fertilization. Development. 2014;141(19):3732-9.

77. Inoue N, Hamada D, Kamikubo H, Hirata K, Kataoka M, Yamamoto M, et al. Molecular dissection of IZUMO1, a sperm protein essential for sperm-egg fusion. Development. 2013;140(15):3221-9.

78. Bianchi E, Doe B, Goulding D, Wright GJ. Juno is the egg Izumo receptor and is essential for mammalian fertilization. Nature. 2014;508(7497):483-7.

79. Yu M, Zhao H, Chen T, Tian Y, Li M, Wu K, et al. Mutational analysis of IZUMO1R in women with fertilization failure and polyspermy after in vitro fertilization. J Assist Reprod Genet. 2018;35(3):539-44.

80. Suzuki B, Sugano Y, Ito J, Saito H, Niimura S, Yamashiro H. Location and expression of Juno in mice oocytes during maturation. JBRA Assist Reprod. 2017;21(4):321-6.

81. Jean C, Haghighirad F, Zhu Y, Chalbi M, Ziyyat A, Rubinstein E, et al. JUNO, the receptor of sperm IZUMO1, is expressed by the human oocyte and is essential for human fertilisation. Hum Reprod. 2019;34(1):118-26.

82. Dai X, Zhang M, Lu Y, Miao Y, Zhou C, Sun S, et al. Melamine impairs female fertility via suppressing protein level of Juno in mouse eggs. PLoS One. 2015;10(12):e0144248.

83. Zhang M, Miao Y, Chen Q, et al. BaP exposure causes oocyte meiotic arrest and fertilization failure to weaken female fertility. FASEB J. 2018;32(1):342-52.

84. Bianchi E, Wright GJ. Cross-species fertilization: the hamster egg receptor, Juno, binds the human sperm ligand, Izumo1. Philos Trans R Soc Lond Ser B Biol Sci. 2015;370(1661):20140101.

85. Yanagimachi R, Yanagimachi H, Rogers BJ. The use of zona-free animal ova as a test-system for the assessment of the fertilizing capacity of human spermatozoa. Biol Reprod. 1976;15(4):471-6.

86. Stricker SA. Comparative biology of calcium signaling during fertilization and egg activation in animals. Dev Biol. 1999;211(2):157-76.

87. Ramadan WM, Kashir J, Jones C, Coward K. Oocyte activation and phospholipase $\mathrm{C}$ zeta (PLCzeta): diagnostic and therapeutic implications for assisted reproductive technology. Cell Commun Signal. 2012;10(1):12.

88. Yeste M, Jones C, Amdani SN, Patel S, Coward K. Oocyte activation deficiency: a role for an oocyte contribution? Hum Reprod Update. 2016;22(1):23-47. 
89. Whitaker M. Calcium at fertilization and in early development. Physiol Rev. 2006;86(1):25-88.

90. Swann K. A cytosolic sperm factor stimulates repetitive calcium increases and mimics fertilization in hamster eggs. Development. 1990;110(4):1295-302.

91. Stice SL, Robl JM. Activation of mammalian oocytes by a factor obtained from rabbit sperm. Mol Reprod Dev. 1990;25(3):27280.

92. Homa ST, Swann K. A cytosolic sperm factor triggers calcium oscillations and membrane hyperpolarizations in human oocytes. Hum Reprod. 1994;9(12):2356-61.

93. Sutovsky P, Manandhar G, Wu A, Oko R. Interactions of sperm perinuclear theca with the oocyte: implications for oocyte activation, anti-polyspermy defense, and assisted reproduction. Microsc Res Tech. 2003;61(4):362-78.

94. Parrington J, Swann K, Shevchenko VI, Sesay AK, Lai FA. Calcium oscillations in mammalian eggs triggered by a soluble sperm protein. Nature. 1996;379(6563):364-8.

95. Sette C, Bevilacqua A, Bianchini A, Mangia F, Geremia R, Rossi P. Parthenogenetic activation of mouse eggs by microinjection of a truncated c-kit tyrosine kinase present in spermatozoa. Development. 1997;124(11):2267-74.

96. Harada Y, Matsumoto T, Hirahara S, Nakashima A, Ueno S, Oda $\mathrm{S}$, et al. Characterization of a sperm factor for egg activation at fertilization of the newt Cynops pyrrhogaster. Dev Biol. 2007;306(2):797-808.

97. Aarabi M, Balakier H, Bashar S, et al. Sperm-derived WW domain-binding protein, PAWP, elicits calcium oscillations and oocyte activation in humans and mice. FASEB J. 2014;28(10): 4434-40.

98. Tavalaee M, Kiani-Esfahani A, Nasr-Esfahani MH. Relationship between potential sperm factors involved in oocyte activation and sperm DNA fragmentation with intra-cytoplasmic sperm injection clinical outcomes. Cell J. 2017;18(4):588-96.

99. Saunders CM, Larman MG, Parrington J, et al. PLC zeta: a spermspecific trigger of $\mathrm{Ca}(2+)$ oscillations in eggs and embryo development. Development. 2002;129(15):3533-44.

100. Cox LJ, Larman MG, Saunders CM, Hashimoto K, Swann K, Lai FA. Sperm phospholipase Czeta from humans and cynomolgus monkeys triggers $\mathrm{Ca} 2+$ oscillations, activation and development of mouse oocytes. Reproduction. 2002;124(5):611-23.

101. Amdani SN, Yeste M, Jones C, Coward K. Phospholipase C zeta (PLCzeta) and male infertility: clinical update and topical developments. Adv Biol Regul. 2016;61:58-67.

102. Knott JG, Kurokawa M, Fissore RA, Schultz RM, Williams CJ. Transgenic RNA interference reveals role for mouse sperm phospholipase Czeta in triggering $\mathrm{Ca} 2+$ oscillations during fertilization. Biol Reprod. 2005;72(4):992-6.

103. Hachem A, Godwin J, Ruas M, Lee HC, Ferrer Buitrago M, Ardestani G, et al. PLCzeta is the physiological trigger of the $\mathrm{Ca}(2+)$ oscillations that induce embryogenesis in mammals but conception can occur in its absence. Development. 2017;144(16):2914-24.

104. Nozawa K, Satouh Y, Fujimoto T, Oji A, Ikawa M. Sperm-borne phospholipase $\mathrm{C}$ zeta-1 ensures monospermic fertilization in mice. Sci Rep. 2018;8(1):1315.

105. Yoon SY, Jellerette T, Salicioni AM, Lee HC, Yoo MS, Coward K, et al. Human sperm devoid of PLC, zeta 1 fail to induce $\mathrm{Ca}(2+)$ release and are unable to initiate the first step of embryo development. J Clin Invest. 2008;118(11):3671-81.

106. Yamaguchi T, Ito M, Kuroda K, Takeda S, Tanaka A. The establishment of appropriate methods for egg-activation by human PLCZ1 RNA injection into human oocyte. Cell Calcium. 2017;65:22-30.

107. Heytens E, Parrington J, Coward K, Young C, Lambrecht S, Yoon $\mathrm{SY}$, et al. Reduced amounts and abnormal forms of phospholipase
C zeta (PLCzeta) in spermatozoa from infertile men. Hum Reprod. 2009;24(10):2417-28.

108. Kashir J, Konstantinidis M, Jones C, Heindryckx B, de Sutter P, Parrington J, et al. Characterization of two heterozygous mutations of the oocyte activation factor phospholipase C zeta (PLCzeta) from an infertile man by use of minisequencing of individual sperm and expression in somatic cells. Fertil Steril. 2012;98(2): 423-31.

109. Heindryckx B, Van der Elst J, De Sutter P, Dhont M. Treatment option for sperm- or oocyte-related fertilization failure: assisted oocyte activation following diagnostic heterologous ICSI. Hum Reprod. 2005;20(8):2237-41.

110. Heindryckx B, De Gheselle S, Gerris J, Dhont M, De Sutter P. Efficiency of assisted oocyte activation as a solution for failed intracytoplasmic sperm injection. Reprod BioMed Online. 2008;17(5):662-8.

111. Nomikos M, Theodoridou M, Elgmati K, Parthimos D, Calver BL, Buntwal L, et al. Human PLCzeta exhibits superior fertilization potency over mouse PLCzeta in triggering the $\mathrm{Ca}(2+)$ oscillations required for mammalian oocyte activation. Mol Hum Reprod. 2014;20(6):489-98.

112. Ebner T, Montag M. Artificial oocyte activation: evidence for clinical readiness. Reprod BioMed Online. 2016;32(3):271-3.

113. Rogers NT, Hobson E, Pickering S, Lai FA, Braude P, Swann K. Phospholipase Czeta causes Ca2+ oscillations and parthenogenetic activation of human oocytes. Reproduction. 2004;128(6):697702 .

114. Gardner AJ, Evans JP. Mammalian membrane block to polyspermy: new insights into how mammalian eggs prevent fertilisation by multiple sperm. Reprod Fertil Dev. 2006;18(12):53-61.

115. Jaffe LA. Fast block to polyspermy in sea urchin eggs is electrically mediated. Nature. 1976;261(5555):68-71.

116. Wozniak KL, Carlson AE. Ion channels and signaling pathways used in the fast polyspermy block. Mol Reprod Dev. 2019;1-8.

117. Dale B, DeFelice L. Polyspermy prevention: facts and artifacts? J Assist Reprod Genet. 2011;28(3):199-207.

118. Maleszewski M, Kimura Y, Yanagimachi R. Sperm membrane incorporation into oolemma contributes to the oolemma block to sperm penetration: evidence based on intracytoplasmic sperm injection experiments in the mouse. Mol Reprod Dev. 1996;44(2): 256-9.

119. Sengoku K, Tamate K, Takaoka Y, Horikawa M, Goishi K, Okada $\mathrm{R}$, et al. Requirement of sperm-oocyte plasma membrane fusion for establishment of the plasma membrane block to polyspermy in human pronuclear oocytes. Mol Reprod Dev. 1999;52(2):183-8.

120. Gulyas BJ. Cortical granules of mammalian eggs. Int Rev Cytol. 1980;63:357-92.

121. Cheeseman LP, Boulanger J, Bond LM, Schuh M. Two pathways regulate cortical granule translocation to prevent polyspermy in mouse oocytes. Nat Commun. 2016;7:13726.

122. Vogt EJ, Tokuhiro K, Guo M, Dale R, Yang G, Shin SW, et al. Anchoring cortical granules in the cortex ensures trafficking to the plasma membrane for post-fertilization exocytosis. Nat Commun. 2019;10(1):2271.

123. Liu M. The biology and dynamics of mammalian cortical granules. Reprod Biol Endocrinol. 2011;9:149.

124. Miao YL, Kikuchi K, Sun QY, Schatten H. Oocyte aging: cellular and molecular changes, developmental potential and reversal possibility. Hum Reprod Update. 2009;15(5):573-85.

125. Gahlay G, Gauthier L, Baibakov B, Epifano O, Dean J. Gamete recognition in mice depends on the cleavage status of an egg's zona pellucida protein. Science. 2010;329(5988):216-9.

126. Burkart AD, Xiong B, Baibakov B, Jimenez-Movilla M, Dean J. Ovastacin, a cortical granule protease, cleaves ZP2 in the zona pellucida to prevent polyspermy. J Cell Biol. 2012;197(1):37-44. 
127. Schroeder AC, Schultz RM, Kopf GS, Taylor FR, Becker RB, Eppig JJ. Fetuin inhibits zona pellucida hardening and conversion of ZP2 to ZP2f during spontaneous mouse oocyte maturation in vitro in the absence of serum. Biol Reprod. 1990;43(5):891-7.

128. Dietzel E, Wessling J, Floehr J, Schäfer C, Ensslen S, Denecke B, et al. Fetuin-B, a liver-derived plasma protein is essential for fertilization. Dev Cell. 2013;25(1):106-12.

129. Dietzel E, Floehr J, Van de Leur E, Weiskirchen R, JahnenDechent W. Recombinant fetuin-B protein maintains high fertilization rate in cumulus cell-free mouse oocytes. Mol Hum Reprod. 2017;23(1):25-33.

130. Floehr J, Dietzel E, Neulen J, Rosing B, Weissenborn U, JahnenDechent W. Association of high fetuin-B concentrations in serum with fertilization rate in IVF: a cross-sectional pilot study. Hum Reprod. 2016;31(3):630-7.

131. Fang L, Hu X, Cui L, Lv P, Ma X, Ye Y. Serum and follicular fluid fetuin-B levels are correlated with fertilization rates in conventional IVF cycles. J Assist Reprod Genet. 2019;36(6):1101-7.

132. Floehr J, Dietzel E, Schmitz C, Chappell A, Jahnen-Dechent W. Down-regulation of the liver-derived plasma protein fetuin-B mediates reversible female infertility. Mol Hum Reprod. 2017;23(1): $34-44$.

133. Kim AM, Bernhardt ML, Kong BY, Ahn RW, Vogt S, Woodruff $\mathrm{TK}$, et al. Zinc sparks are triggered by fertilization and facilitate cell cycle resumption in mammalian eggs. ACS Chem Biol. 2011;6(7):716-23.

134. Bernhardt ML, Kong BY, Kim AM, O'Halloran TV, Woodruff TK. A zinc-dependent mechanism regulates meiotic progression in mammalian oocytes. Biol Reprod. 2012;86(4):114.

135. Que EL, Bleher R, Duncan FE, Kong BY, Gleber SC, Vogt S, et al. Quantitative mapping of zinc fluxes in the mammalian egg reveals the origin of fertilization-induced zinc sparks. Nat Chem. 2015;7(2):130-9.

136. Zhang N, Duncan FE, Que EL, O'Halloran TV, Woodruff TK. The fertilization-induced zinc spark is a novel biomarker of mouse embryo quality and early development. Sci Rep. 2016;6:22772.

137. Duncan FE, Que EL, Zhang N, Feinberg EC, O'Halloran TV, Woodruff TK. The zinc spark is an inorganic signature of human egg activation. Sci Rep. 2016;6:24737.

138. Que EL, Duncan FE, Bayer AR, Philips SJ, Roth EW, Bleher R, et al. Zinc sparks induce physiochemical changes in the egg zona pellucida that prevent polyspermy. Integr Biol (Camb). 2017;9(2): 135-44.

139. Que EL, Duncan FE, Lee HC, Hornick JE, Vogt S, Fissore RA, et al. Bovine eggs release zinc in response to parthenogenetic and sperm-induced egg activation. Theriogenology. 2019;127:41-8.

140. Kerns K, Zigo M, Drobnis EZ, Sutovsky M, Sutovsky P. Zinc ion flux during mammalian sperm capacitation. Nat Commun. 2018;9(1):2061.

141. Lee K, Davis A, Zhang L, Ryu J, Spate LD, Park KW, et al. Pig oocyte activation using a $\mathrm{Zn}(2)(+)$ chelator, TPEN. Theriogenology. 2015;84(6):1024-32.

142. de Macedo MP, Glanzner WG, Rissi VB, Gutierrez K, Currin L, Baldassarre $\mathrm{H}$, et al. A fast and reliable protocol for activation of porcine oocytes. Theriogenology. 2019;123:22-9.

143. Jeon Y, Yoon JD, Cai L, Hwang SU, Kim E, Zheng Z, et al. Supplementation of zinc on oocyte in vitro maturation improves preimplatation embryonic development in pigs. Theriogenology. 2014;82(6):866-74.

144. Ho PC, Yeung WS, Chan YF, So WW, Chan ST. Factors affecting the incidence of polyploidy in a human in vitro fertilization program. Int J Fertil Menopausal Stud. 1994;39(1):14-9.

145. Hassold T, Chen N, Funkhouser J, Jooss T, Manuel B, Matsuura J, et al. A cytogenetic study of 1000 spontaneous abortions. Ann Hum Genet. 1980;44(2):151-78.

146. Byrne J, Warburton D, Kline J, Blanc W, Stein Z. Morphology of early fetal deaths and their chromosomal characteristics. Teratology. 1985;32(2):297-315.

147. Menten B, Swerts K, Delle Chiaie B, et al. Array comparative genomic hybridization and flow cytometry analysis of spontaneous abortions and mors in utero samples. BMC Med Genet. 2009; $10: 89$.

148. Jacobs PA, Angell RR, Buchanan IM, Hassold TJ, Matsuyama AM, Manuel B. The origin of human triploids. Ann Hum Genet. 1978;42(1):49-57.

149. Bieber FR, Nance WE, Morton CC, Brown JA, Redwine FO, Jordan RL, et al. Genetic studies of an acardiac monster: evidence of polar body twinning in man. Science. 1981;213(4509):775-7.

150. McNamara HC, Kane SC, Craig JM, Short RV, Umstad MP. A review of the mechanisms and evidence for typical and atypical twinning. Am J Obstet Gynecol. 2016;214(2):172-91.

151. Gabbett MT, Laporte J, Sekar R, Nandini A, McGrath P, Sapkota $\mathrm{Y}$, et al. Molecular support for heterogonesis resulting in sesquizygotic twinning. N Engl J Med. 2019;380(9):842-9.

152. Hendriks S, Dancet EA, van Pelt AM, Hamer G, Repping S. Artificial gametes: a systematic review of biological progress towards clinical application. Hum Reprod Update. 2015;21(3):28596.

153. Vassena R, Heindryckx B, Peco R, et al. Genome engineering through CRISPR/Cas9 technology in the human germline and pluripotent stem cells. Hum Reprod Update. 2016;22(4):411-9.

154. Clift D, McEwan WA, Labzin LI, Konieczny V, Mogessie B, James LC, et al. A method for the acute and rapid degradation of endogenous proteins. Cell. 2017;171(7):1692-706 e1618.

155. Clift D, So C, McEwan WA, James LC, Schuh M. Acute and rapid degradation of endogenous proteins by Trim-Away. Nat Protoc. 2018;13(10):2149-75.

156. Jones S, Lukanowska M, Suhorutsenko J, Oxenham S, Barratt C, Publicover S, et al. Intracellular translocation and differential accumulation of cell-penetrating peptides in bovine spermatozoa: evaluation of efficient delivery vectors that do not compromise human sperm motility. Hum Reprod. 2013;28(7):1874-89.

157. Morris J, Jones S, Howl J, Lukanowska M, Lefievre L, Publicover S. Cell-penetrating peptides, targeting the regulation of storeoperated channels, slow decay of the progesterone-induced [Ca2+]i signal in human sperm. Mol Hum Reprod. 2015;21(7): 563-70.

158. Ohto U, Ishida H, Krayukhina E, Uchiyama S, Inoue N, Shimizu T. Structure of IZUMO1-JUNO reveals sperm-oocyte recognition during mammalian fertilization. Nature. 2016;534(7608):566-9.

Publisher's note Springer Nature remains neutral with regard to jurisdictional claims in published maps and institutional affiliations. 